\title{
Central retinal vein occlusion in people aged 40 years or less: a review of 17 patients
}

\author{
R F Walters, D J Spalton
}

\begin{abstract}
Seventeen patients with central retinal vein occlusion aged 40 or under were reviewed. Ocular involvement was characteristically unilateral, with moderate degrees of retinal haemorrhage, little retinal ischaemia, and a tendency to optic disc swelling. Visual prognosis was good. Follow-up showed that most patients have good general health and no involvement of the fellow eye. There was little evidence to support an inflammatory aetiology or underlying vascular disease in most of the patients. An alternative explanation for the development of CRVO in young patients might be a congenital anomaly of the central retinal vein.
\end{abstract}

Central retinal vein occlusion (CRVO) is usually seen as a disease of the elderly, when it is frequently associated with arteriosclerotic or atherogenic disease elsewhere, glaucoma, or factors which affect blood coagulability and viscosity. It is less common in younger people. In two large studies ${ }^{12}$ of CRVO 11 of 116 patients $(10 \%)$ and approximately 14 of 179 patients $(8 \%)$ were aged 40 years or less.

Attention was first focused on these younger patients by Lyle and Wybar ${ }^{3}$ in 1961, who described seven patients, though on review probably only five of these had CRVO. These patients ranged in age from 24 to 49 years. The authors drew attention to the characteristic fundal appearances of unilateral disc swelling, namely, venous dilatation and peripheral retinal haemorrhages in the presence of good visual acuity. They emphasised a male preponderance and the fact that the patients were otherwise well and made a full visual recovery. Three patients were followed up for 3,5 , and 6 years respectively and suffered no further problems. In the absence of overt causes for the CRVO they postulated that a vasculitis of the central retinal vein was responsible, making an analogy with Eales' disease.

This report was followed by another description of five cases by Lonn and Hoyt, ${ }^{4}$ who coined the term 'papillophlebitis'. They thought the aetiology was inflammatory on the grounds that whitish sheathing of the retinal veins adjacent to the optic disc could be seen after the swelling had subsided. Soon afterwards further cases were published by Cogan, ${ }^{5}$ Hart et al,${ }^{6}$ and Hayreh. ${ }^{7}$ The last two reports published fluorescein angiograms showing that the appearances were not dissimilar to those of non-ischaemic CRVO in older patients. Hart et al postulated that the better visual prognosis was due to the absence of associated arterial disease. All these authors, however, subscribed to the view of an inflam- matory aetiology, though direct evidence to support this concept is lacking.

Premature vascular disease is always a worrying finding both for the physician and the patient. We have retrospectively reviewed 17 patients, aged 40 years or younger who presented with a CRVO, with a view to seeking the underlying aetiology and to ascertain the general and visual prognosis.

\section{Material and methods}

From the diagnostic index for fundus photography at St Thomas's Hospital we identified 182 patients diagnosed as having a central retinal vein occlusion between 1968 and 1984. This would be only a proportion of the patients seen with this condition at the hospital, as fundus photography is not routinely performed on all patients. Of the 182 patients 142 had adequate documentation for the purpose of this study.

From the hospital records we identified the date of presentation and age of the patients. Twenty-one patients were aged 40 or under at presentation, and these were selected for special study. Both records and colour photographs were available for only 17 , and most of these had also had fluorescein angiography (Table I). Particular attention was paid on review of the notes to any evidence of systemic disease on presentation and to the presence of possible aetiological factors such as hypertension, smoking, diabetes mellitus, the contraceptive pill, and a family history of vascular disease. As this was a retrospective study full data were not available for all patients, and these findings are summarised (Table II) together with the results of investigations at presentation (Table III).

Central retinal vein occlusion was defined as venous dilatation with retinal haemorrhages scattered throughout the fundus to the periphery. The severity of the retinopathy was

TABLE I Details of the 17 patients studied in depth

\begin{tabular}{llll}
\hline Patient & Age & Sex & Date of onset \\
\hline A & 28 & F & Jan 1976 \\
B & 38 & F & Mar 1981 \\
C & 37 & F & July 1975 \\
D & 38 & M & Jan 1979 \\
E & 28 & Jan 1975 \\
F & 33 & M & Oct 1980 \\
G & 33 & F & Oct 1976 \\
H & 33 & M & Dec 1975 \\
I & 34 & M & Sept 1978 \\
J & 37 & M & July 1973 \\
K & 22 & Mar 1979 & Aug 1982 \\
L & 23 & M & Dec 1983 \\
M & 28 & F & June 1979 \\
N & 39 & M & Oct 1974 \\
O & 35 & M & Oct 1979 \\
P & 35 & M & Nov 1981 \\
Q & 14 & & \\
\hline
\end{tabular}

Average age $=31 \cdot 5$ years. Male/female ratio $=10: 7$. 
TABLE II Possible predisposing factors in the 17 patients studied

\begin{tabular}{|c|c|c|c|c|c|c|c|}
\hline Patient & $\begin{array}{l}\text { Systemic } \\
\text { hyper- } \\
\text { tension }\end{array}$ & $\begin{array}{l}\text { Diabetes } \\
\text { mellitus }\end{array}$ & Smoker & $\begin{array}{l}\text { Contra- } \\
\text { ceptive } \\
\text { pill }\end{array}$ & $\begin{array}{l}\text { Vascular } \\
\text { disease }\end{array}$ & $\begin{array}{l}\text { Ocular } \\
\text { disease }\end{array}$ & $\begin{array}{l}\text { Other systemic } \\
\text { disease }\end{array}$ \\
\hline A & - & - & - & - & - & - & Asthma \\
\hline B & - & + & - & + & - & - & - \\
\hline $\bar{C}$ & - & + & - & - & $\begin{array}{l}\text { Raynaud's } \\
\text { phenomenon }\end{array}$ & - & - \\
\hline D & - & - & + & NR & - & $\begin{array}{l}\text { Ocular } \\
\text { hyper- } \\
\text { tension }\end{array}$ & - \\
\hline E & - & - & - & - & Migraine & - & $\begin{array}{l}\text { Mitochondrial } \\
\text { myopathy } \\
\text { (later) }\end{array}$ \\
\hline F & - & - & + & NR & - & $\begin{array}{l}\text { Anterior } \\
\text { uveitis }\end{array}$ & $\begin{array}{l}\text { Ankylosing } \\
\text { spondylitis }\end{array}$ \\
\hline G & - & - & - & - & - & - & $\begin{array}{l}\text { Iron deficiency } \\
\text { anaemia }\end{array}$ \\
\hline $\mathrm{H}$ & - & - & + & NR & - & - & - \\
\hline I & - & - & $\begin{array}{l}\text { Gave up } \\
2 \text { years } \\
\text { ago }\end{array}$ & NR & - & - & - \\
\hline $\mathrm{J}$ & - & - & - & NR & Migraine & - & - \\
\hline $\mathrm{K}$ & - & - & + & NR & - & - & - \\
\hline $\mathrm{L}$ & - & - & - & + & - & - & - \\
\hline $\bar{M}$ & - & - & - & NR & - & - & - \\
\hline $\mathrm{N}$ & - & - & NK & - & - & - & - \\
\hline 0 & - & - & - & NR & - & - & - \\
\hline $\mathbf{P}$ & - & NK & NK & NR & - & - & - \\
\hline Q & - & - & - & NR & - & - & $\begin{array}{l}\text { Non-specific } \\
\text { immunological } \\
\text { illness }\end{array}$ \\
\hline
\end{tabular}

assessed by grading the physical signs seen on the fundus photography and fluorescein angiogram as follows: $(a)$ the degree of retinal haemorrhage (on scale 1-5); (b) the degree of optic disc swelling (on scale $0-4$ ); and (c) the degree of retinal ischaemia (on scale $0-4$ ). Associated other findings, such as cilioretinal artery occlusion and disc cupping were noted separately.

All 17 patients were sent a follow-up questionnaire by post and replies were received from nine. This questionnaire sought to elicit a more detailed history of the atherogenic factors at the time of the initial illness and to inquire about the visual recovery or further problems with their vision or general health since presentation.

\section{Results}

The average age of the 142 patients was 58.6 years, with 82 men (average age 60.2 years) and 58 women (average age $56 \cdot 2$ years). The sex of two patients could not be ascertained with certainty from the records. These were over 40 and are included in the overall data but omitted from

\footnotetext{
$+=$ Present.$-=$ Absent. $\mathrm{NK}=$ not known. $\mathrm{NR}=$ not relevant.
}

TABLE III Summary of investigations

\begin{tabular}{|c|c|c|c|c|c|c|c|c|c|c|}
\hline & $F B C$ & $\begin{array}{l}E S R \\
(m m / h)\end{array}$ & $\begin{array}{l}\text { Plasma } \\
\text { fibrinogen } \\
\text { normal range } \\
(2 \cdot 0-4.0 \mathrm{~g} / \mathrm{l})\end{array}$ & $\begin{array}{l}\text { Serum } \\
\text { proteins }\end{array}$ & $\begin{array}{l}\text { Serum } \\
\text { choles- } \\
\text { terol }\end{array}$ & $\begin{array}{l}\text { Serum } \\
\text { tri- } \\
\text { glyceride }\end{array}$ & $\begin{array}{l}\text { VDRL } \\
T P H A\end{array}$ & $\begin{array}{l}\text { Random } \\
\text { blood } \\
\text { sugar }\end{array}$ & $C X R$ & Others \\
\hline $\begin{array}{l}\mathrm{A} \\
\mathrm{B} \\
\mathrm{C} \\
\mathrm{D}\end{array}$ & $\begin{array}{l}\mathbf{N} \\
\mathbf{N} \\
\mathbf{N} \\
\mathbf{N}\end{array}$ & $\begin{array}{r}4 \\
4 \\
13 \\
14\end{array}$ & $\begin{array}{l}\text { NK } \\
\text { NK } \\
\text { NK } \\
\text { N }\end{array}$ & $\begin{array}{l}\mathrm{N} \\
\mathrm{NK} \\
\mathrm{NK} \\
\mathrm{N}\end{array}$ & $\begin{array}{l}\text { NK } \\
\text { NK } \\
\text { N } \\
N\end{array}$ & $\begin{array}{l}\text { NK } \\
\text { NK } \\
\text { N } \\
\text { N }\end{array}$ & $\begin{array}{l}\text { NK } \\
\text { NK } \\
-v e \\
-v e\end{array}$ & $\begin{array}{l}\mathbf{N} \\
N(D M) \\
\quad(D M) \\
N\end{array}$ & $\begin{array}{l}\text { NK } \\
\text { NK } \\
\text { N } \\
\text { N }\end{array}$ & \multirow{5}{*}{$\begin{array}{l}\text { Sicklecell } \\
\text { - ve } \\
\text { + ve ANF } \\
\text { 1:250 } \\
\text { HLA B27 } \\
\text { + ve } \\
\text { + ve ANF } \\
1: 10\end{array}$} \\
\hline $\mathbf{E}$ & $\mathbf{N}$ & 15 & $\mathbf{N}$ & $\mathbf{N}$ & $\mathbf{N}$ & $\mathrm{N}$ & NK & $\mathbf{N}$ & NK & \\
\hline $\mathbf{F}$ & $\mathrm{N}$ & 11 & $\mathbf{N}$ & $\mathrm{N}$ & NK & NK & - ve & $\mathbf{N}$ & NK & \\
\hline $\begin{array}{l}\mathrm{G} \\
\mathrm{H}\end{array}$ & $\underset{\mathrm{N}}{\downarrow}(9 \cdot 0 \mathrm{~g} / \mathrm{dl})$ & $\begin{array}{l}5 \\
2\end{array}$ & $\begin{array}{l}\mathbf{N} \\
\mathbf{N}\end{array}$ & $\begin{array}{l}\mathbf{N} \\
\mathbf{N}\end{array}$ & $\begin{array}{l}\mathrm{NK} \\
\mathrm{N}\end{array}$ & $\begin{array}{l}\mathrm{NK} \\
\mathrm{N}\end{array}$ & $\begin{array}{l}\mathrm{NK} \\
-\mathrm{ve}\end{array}$ & $\begin{array}{l}\mathbf{N} \\
\mathbf{N}\end{array}$ & $\begin{array}{l}\mathrm{NK} \\
\mathrm{N}\end{array}$ & \\
\hline $\begin{array}{l}\text { I } \\
\text { J } \\
\text { K } \\
\text { L } \\
\text { M } \\
\text { N } \\
\text { O } \\
\text { P } \\
\text { Q }\end{array}$ & $\begin{array}{l}\mathbf{N} \\
\mathbf{N} \\
\mathbf{N} \\
\mathbf{N} \\
\mathbf{N} \\
\mathbf{N} \\
\mathbf{N} \\
\underset{\downarrow}{\downarrow}(10 \cdot 7 \mathrm{~g} / \mathrm{dl})\end{array}$ & $\begin{array}{c}6 \\
12 \\
1 \\
4 \\
4 \\
\mathrm{NK} \\
18 \\
\mathrm{NK} \\
43\end{array}$ & $\begin{array}{l}\text { N } \\
\text { NK } \\
\text { N } \\
\text { N } \\
\text { NK } \\
\text { NK } \\
\text { N } \\
\text { NK } \\
\text { NK }\end{array}$ & $\begin{array}{l}\mathbf{N} \\
\mathbf{N} \\
\mathbf{N} \\
\mathbf{N} \\
\mathbf{N} \\
\mathbf{N} \\
\mathbf{N} \\
\mathbf{N K} \\
\mathrm{NK}\end{array}$ & $\begin{array}{l}\text { N } \\
\text { NK } \\
\text { N } \\
\text { NK } \\
\text { N } \\
\text { NK } \\
\text { N } \\
\text { NK } \\
\text { NK }\end{array}$ & $\begin{array}{l}\text { N } \\
\text { NK } \\
\text { N } \\
\text { NK } \\
\text { N } \\
\text { NK } \\
\text { N } \\
\text { NK } \\
\text { NK }\end{array}$ & $\begin{array}{l}- \text { ve } \\
\text { NK } \\
- \text { ve } \\
- \text { ve } \\
\text { NK } \\
\text { NK } \\
- \text { ve } \\
\text { NK } \\
\text { NK }\end{array}$ & $\begin{array}{l}\text { N } \\
\text { N } \\
\text { N } \\
\text { N } \\
\text { NK } \\
\text { NK } \\
\text { N } \\
\text { NK } \\
\text { NK }\end{array}$ & $\begin{array}{l}\text { NK } \\
\text { N } \\
\text { N } \\
\text { N } \\
\text { NK } \\
\text { NK } \\
\text { N } \\
\text { NK } \\
\text { NK }\end{array}$ & \\
\hline
\end{tabular}

$\mathrm{N}=$ normal. $\mathrm{DM}=$ diabetes mellitus. ANF = antinuclear factor test. $\mathrm{NK}=$ not known. $\downarrow=$ reduced.

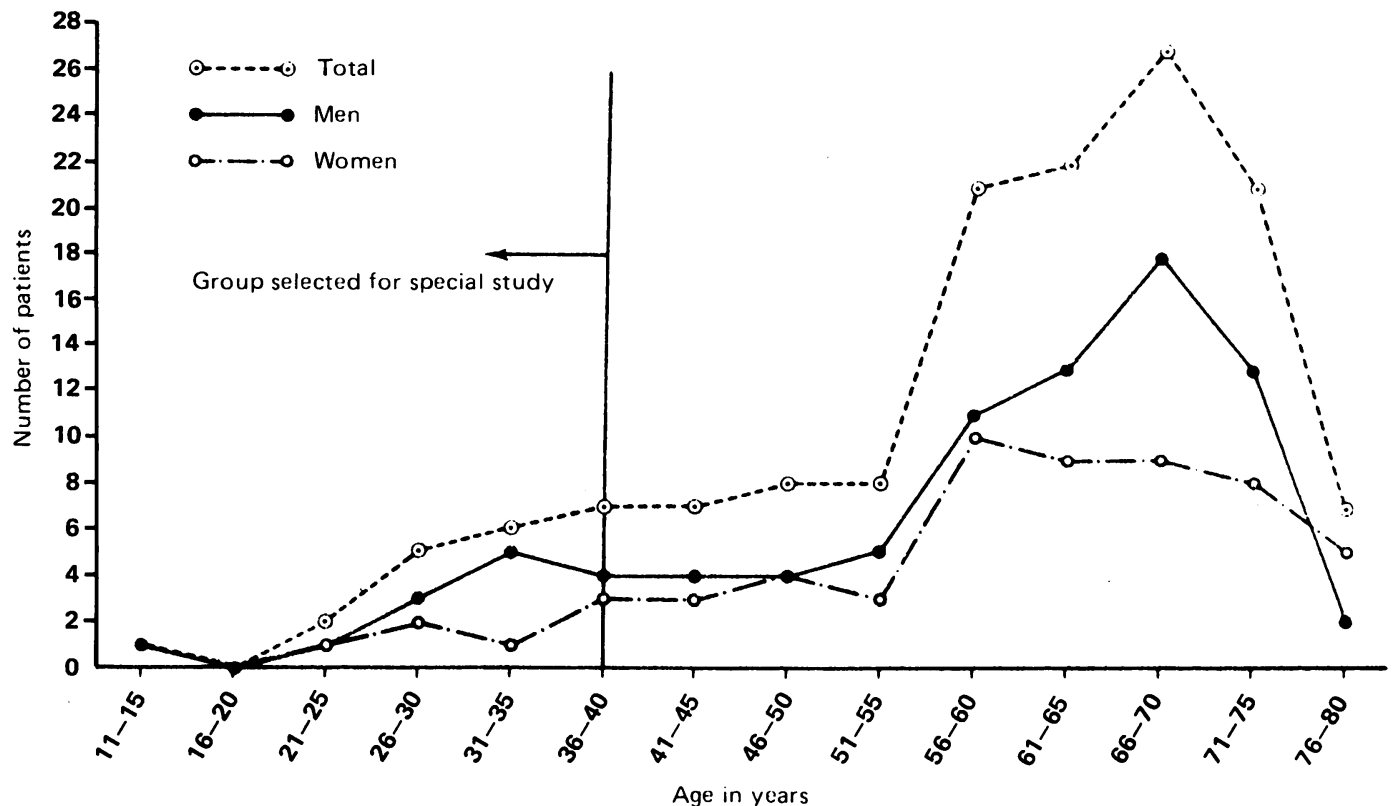

Figure 1: Distribution by age and sex of 142 patients with central retinal vein occlusion. 
TABLE IV Assessment of severity of CRVO and visual outcome

\begin{tabular}{llllll}
\hline & $\begin{array}{l}\text { Optic disc } \\
\text { swelling, } \\
\text { grade 0-4 }\end{array}$ & $\begin{array}{l}\text { Retinal } \\
\text { haemorrhage, } \\
\text { grade 1-5 }\end{array}$ & $\begin{array}{l}\text { Degree of retinal } \\
\text { ischaemia, } \\
\text { grade 0-4 }\end{array}$ & $\begin{array}{l}\text { VA in affected } \\
\text { eye at present- } \\
\text { ation }\end{array}$ & $\begin{array}{l}\text { Latest } \\
\text { known }\end{array}$ \\
\hline A & 2 & 1 & 0 & $6 / 6$ & $6 / 6$ \\
B & 3 & 3 & 0 & $6 / 60$ & $6 / 18$ \\
C & 0 & 2 & 0 & $6 / 5$ & NK \\
D & 0 & 3 & 0 & $6 / 5$ & $6 / 5$ \\
E & 2 & 3 & 1 & $6 / 24$ & $6 / 5$ \\
F & 3 & 3 & 1 & $6 / 24$ & $6 / 36$ \\
G & 0 & 1 & 0 & $6 / 5$ & $6 / 5$ \\
H & 4 & 5 & 3 & C.F & .F \\
I & 0 & 1 & 0 & $6 / 9$ & NK \\
J & 2 & 3 & 1 & $6 / 4$ & NK \\
K & 1 & 1 & 0 & $6 . F$ & $6 / 9$ \\
L & 0 & 1 & 0 & $6 / 36$ & NK \\
M & 1 & 1 & 0 & $6 / 36$ & $6 / 5$ \\
N & 3 & 2 & 0 & $6 / 60$ & NK \\
O & 3 & 3 & 0 & $6 / 9$ & $6 / 24$ \\
P & 0 & 3 & 0 & P.L & \\
Q & 2 & 3 & 0 & & \\
\hline
\end{tabular}

NK= not known.

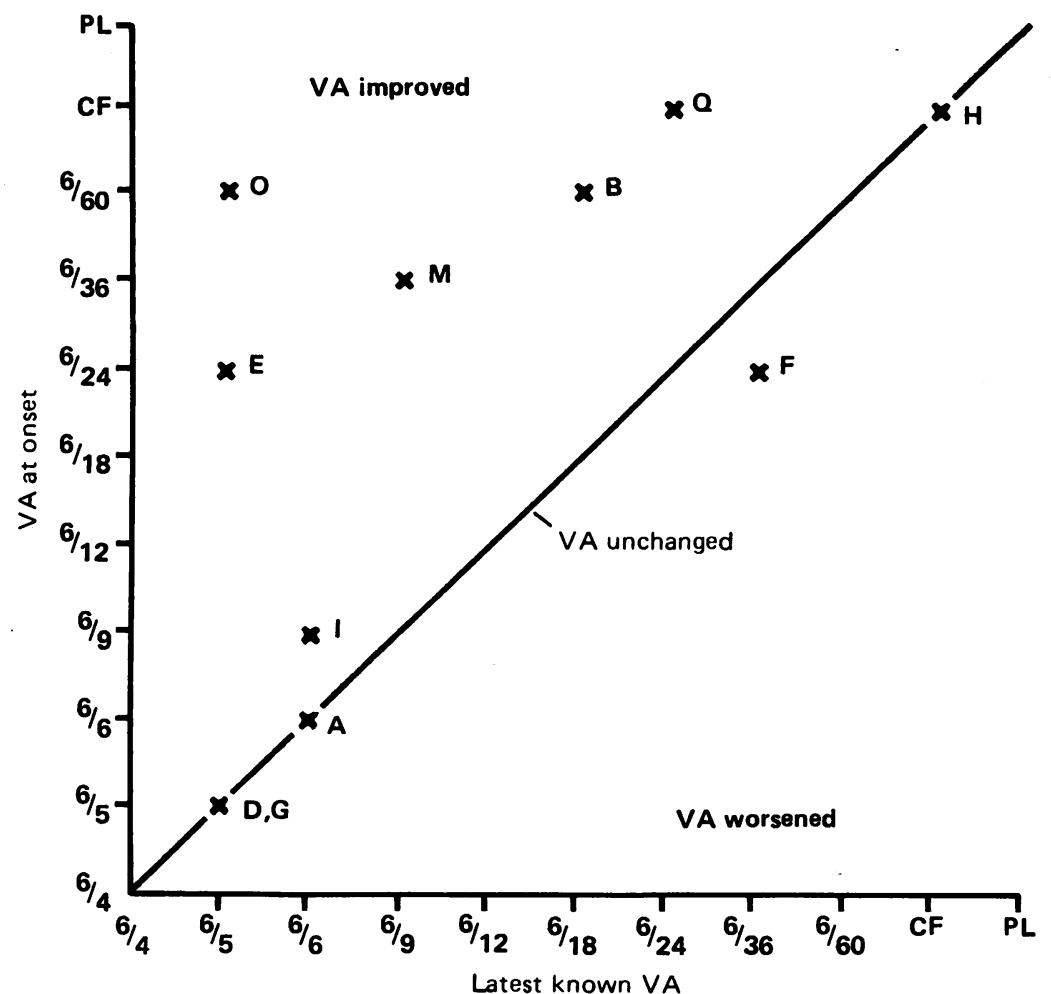

Figure 2: Visual prognosis of the 11 patients with follow-up data (data not available for remaining six patients).

TABLE V Summary of follow-up times and possible aetiological factors

\begin{tabular}{|c|c|c|c|}
\hline Patient & $\begin{array}{l}\text { Length of } \\
\text { follow-up }\end{array}$ & Comments & $\begin{array}{l}\text { Known possible thrombotic or } \\
\text { atherogenic factors }\end{array}$ \\
\hline${ }^{\star} \mathbf{A}$ & $\begin{array}{l}9 \text { years } 2 \text { months } \\
4 \text { years }\end{array}$ & $\begin{array}{l}\text { Had CVA } 8 \text { years later } \\
\text { - }\end{array}$ & $\begin{array}{l}\text { Diabetic (poor control). Pill. FH } \\
\text { of hypertention and heart disease }\end{array}$ \\
\hline $\begin{array}{l}\text { C } \\
\text { D } \\
\text { E }\end{array}$ & $\begin{array}{l}\text { None } \\
5 \text { years } 7 \text { months } \\
9 \text { years } 4 \text { months }\end{array}$ & $\begin{array}{l}\text { Raynaud's disease } \\
\text { Ocular hypertension } \\
\text { Migraine. Diagnosed } \\
\text { mitochondrial myopathy } 2 \text { years } \\
\text { later }\end{array}$ & $\begin{array}{l}\text { Diabetic } \\
\text { Smoker } \\
\text { - }\end{array}$ \\
\hline${ }^{\star} \mathrm{F}$ & $\begin{array}{l}4 \text { years } 6 \text { months } \\
8 \text { years } 5 \text { months }\end{array}$ & $\begin{array}{l}\text { Ankylosing spondylitis. Iritis } \\
\text { Developed gall stones. Iron } \\
\text { deficiency anaemia }(9 \cdot 0 \mathrm{~g} / \mathrm{dl}) \\
\text { Positive ANF }(1: 250)\end{array}$ & $\begin{array}{l}\text { Smoker } \\
\text { Overweight. FH of heart disease }\end{array}$ \\
\hline $\begin{array}{l}{ }^{\star} \mathbf{H} \\
\mathbf{I} \\
\mathbf{J} \\
\mathbf{K} \\
\mathbf{L} \\
{ }^{\star} \mathbf{M}\end{array}$ & $\begin{array}{l}9 \text { years } 3 \text { months } \\
6 \text { years } 6 \text { months } \\
7 \text { months } \\
\text { None } \\
\text { None } \\
1 \text { year } 3 \text { months }\end{array}$ & $\begin{array}{l}\text { Positive ANF }(1: 10) \\
\overline{\text { Migraine }} \\
\overline{\text { Asthmatic }} \\
-\end{array}$ & $\begin{array}{l}\text { Smoker. FH of hypertension } \\
\text { Smoker until } 2 \text { years previously } \\
\text { Smoker } \\
\text { Pill } \\
\text { FH of hypertension and heart } \\
\text { disease }\end{array}$ \\
\hline $\begin{array}{r}\star \mathbf{N} \\
\mathbf{O} \\
{ }_{\mathrm{P}} \\
\mathrm{Q}\end{array}$ & $\begin{array}{l}5 \text { years } 9 \text { months } \\
1 \text { year } \\
5 \text { years } 5 \text { months } \\
2 \text { years } 6 \text { months }\end{array}$ & $\begin{array}{l}\text { Developed gall stones } \\
- \\
\overline{1} \\
1 \text { year later CRVO in other eye. } \\
\text { Non-specific immunological } \\
\text { illness }\end{array}$ & $\begin{array}{l}\text { Overweight } \\
\text { FH of heart disease }\end{array}$ \\
\hline
\end{tabular}

FH=family history. ANF = antinuclear factor test. ${ }^{\star}$ Those who replied to questionnaire. the male/female ratios. The distribution of CRVO by age and sex is shown in Figure 1.

Twenty-one patients $(14.8 \%)$ were aged 40 years or younger. Of the 17 with full data available the average age was 31.5 years, with 10 men (average age 32.9 years) and 7 women (average 30.9 years). The age and sex distribution of these patients is shown in Figure 1 prior to the demarcation line. Of these 17 patients 12 were Caucasian, 2 Asian, 2 Negro, and 1 Arabic, which probably reflects the local population mixture at this time.

Tables I to III summarise epidemiological data, systemic associations, and investigations. Table IV and Figure 2 summarise the ocular findings and visual prognosis. Most patients had mild degrees of retinal haemorrhage, little retinal ischaemia, and a tendency to optic disc swelling with a good visual prognosis. Seven patients of the 17 had a presenting visual acuity in the affected eye of $6 / 36$ or worse. Of these, two (patients $\mathrm{K}$ and $\mathrm{Q}$ ) also had cilioretinal artery occlusion and $\mathrm{O}$ had an occlusion of the macular branch of the superotemporal arteriole. B (a diabetic) had macular exudates (no diabetic changes in the fellow eye), and the remaining three $(H, M, N)$ all had macular oedema. The visual prognosis was in general good (Table IV and Figure 2), and only two patients $(F, H)$ of the 11 patients for whom data were available were known to have a VA in the affected eye of $6 / 36$ or less on follow-up. Of these, F's visual deterioration was probably due to his anterior uveitis (he had ankylosing spondylitis), and $\mathrm{H}$ had macular oedema at presentation. Seven of these 11 patients had a follow-up VA of $6 / 9$ or better. Other notable ocular features were a tendency to optic disc swelling (11 out of 17) and a paucity of signs of retinal ischaemia (in only four patients, and this was comparitively mild), with no patients developing rubeosis iridis. Only one person had raised intraocular pressures $(24,17$ $\mathrm{mmHg}$ ), and none had overt glaucoma.

As this was a selected group from a retrospective study, the information on systemic associations and abnormal investigations at presentation was not complete in all cases. However, because of their relative youth most were investigated carefully. Factors which are associated with atherogenesis or thrombosis (diabetes mellitus, smoking, obesity, contraceptive pill) were found in 10 patients (Table V), and if a family history of heart disease is taken as a predisposition to atherogenesis a further two patients would be included. Two patients also had an immunological illness - F with ankylosing spondylitis and $Q$ with non-specific systemic evidence of immune disease. No patients had systemic hypertension or known abnormal lipid -profiles (8 out of 17 were investigated for lipid abnormalities). At presentation $G$ had a positive antinuclear factor test $(\mathrm{ANF}=1: 250)$ and an iron deficiency anaemia $(9 \cdot 0 \mathrm{~g} / \mathrm{dl})$. He later developed a right ptosis and ophthalmoparesis which was ascribed to a mitochondrial myopathy.

The follow-up postal questionnaire provided useful information (Table VI) and extended the average follow-up time from 35.3 months to 60.9 months (range 6 months to 9 years 3 months). Of the nine patients who responded to the question- 
TABLE VI Result of follow-up questionnaire

\begin{tabular}{|c|c|c|c|c|c|c|c|}
\hline Patient & $\begin{array}{l}\text { Length of } \\
\text { follow-up }\end{array}$ & $\begin{array}{l}\text { Atherogenic } \\
\text { factors at } \\
\text { at onset }\end{array}$ & Weight & $\begin{array}{l}\text { Family } \\
\text { history }\end{array}$ & $\begin{array}{l}\text { Subsequent } \\
\text { general } \\
\text { health }\end{array}$ & $\begin{array}{l}\text { Prognosis of } \\
\text { affected } \\
\text { eye }\end{array}$ & $\begin{array}{l}\text { Other ocular } \\
\text { problems }\end{array}$ \\
\hline $\begin{array}{l}\text { A } \\
\text { B }\end{array}$ & $\begin{array}{l}9 \mathrm{yr} 4 \mathrm{~m} \\
4 \mathrm{yr}\end{array}$ & $\begin{array}{l}\text { Nil } \\
\text { Diabetes }\end{array}$ & $\begin{array}{l}\text { Normal } \\
\text { Normal }\end{array}$ & $\begin{array}{l}\text { Nil } \\
\text { Heart disease } \\
\text { + hypertension in } \\
\text { father }\end{array}$ & $\begin{array}{l}\text { CVA } 8 \text { yr later } \\
\text { Good }\end{array}$ & $\begin{array}{l}\text { Improved } \\
\text { Poor }\end{array}$ & $\begin{array}{l}\text { Hemianopia } \\
\text { Nil }\end{array}$ \\
\hline F & 4 yr $6 \mathrm{~m}$ & Smoker & Normal & $\begin{array}{l}\text { Heart disease in } \\
\text { father }\end{array}$ & Good & Poor & $\begin{array}{l}\text { Ank spond } \\
\text { with iritis }\end{array}$ \\
\hline G & 8 yr $5 \mathrm{~m}$ & Nil & Obese & $\begin{array}{l}\text { Heart disease in } \\
\text { grandmother }\end{array}$ & Gall stones & Improved & Nil \\
\hline $\mathbf{H}$ & $9 \mathrm{yr} 3 \mathrm{~m}$ & Smoker & Normal & $\begin{array}{l}\text { Hypertension in } \\
\text { mother }\end{array}$ & Good & Poor & Nil \\
\hline $\begin{array}{l}\text { I } \\
M\end{array}$ & $\begin{array}{l}6 \text { yr } 6 \mathrm{~m} \\
1 \mathrm{yr} 3 \mathrm{~m}\end{array}$ & $\begin{array}{l}\text { Smoker } \\
\text { Nil }\end{array}$ & $\begin{array}{l}\text { Normal } \\
\text { Mildly } \\
\text { Obese }\end{array}$ & $\begin{array}{l}\text { Not known } \\
\text { Heart disease } \\
\text { + hypertension } \\
\text { in father }\end{array}$ & $\begin{array}{l}\text { Good } \\
\text { Good }\end{array}$ & $\begin{array}{l}\text { Poor } \\
\text { Improved }\end{array}$ & $\begin{array}{l}\text { Nil } \\
\text { Nil }\end{array}$ \\
\hline $\begin{array}{l}\mathrm{N} \\
\mathrm{P}\end{array}$ & $\begin{array}{l}5 \mathrm{yr} 9 \mathrm{~m} \\
5 \mathrm{yr} 9 \mathrm{~m}\end{array}$ & $\begin{array}{l}\text { Nil } \\
\text { Nil }\end{array}$ & $\begin{array}{l}\text { Normal } \\
\text { Normal }\end{array}$ & Nil & $\begin{array}{l}\text { Gall stones } \\
\text { Good }\end{array}$ & $\begin{array}{l}\text { Improved } \\
\text { Improved }\end{array}$ & $\begin{array}{l}\text { Nil } \\
\text { Nil }\end{array}$ \\
\hline
\end{tabular}

naire, A had a subsequent cerebrovascular accident (with homonymous hemianopia), $\mathrm{G}$ and $\mathrm{N}$ developed gallstones, and $\mathrm{F}$ (with ankylosing spondylitis) had two further attacks of acute anterior uveitis. The other five remained well. None of these nine patients developed disease in the fellow eye.

\section{Discussion}

The mean age of the 142 patients in this study (58.6 years) is similar to that previously found in other studies ${ }^{8-11}$ and shows that CRVO is a disease of the elderly, but although CRVO is less common in younger patients it is by no means rare. Of our patients $25 \%$ were aged 50 or less and $15 \%$ aged 40 or below. This latter percentage compares with $10 \%$ in Kohner and Cappin's ${ }^{1}$ and $8 \%$ in Vannas and Raitta's series ${ }^{2}$ (both of these series were unselected). Our patients were derived from a photographic index, and as younger patients are more likely to be referred for photography than older ones this will weight the numbers accordingly and is likely to account for the increased incidence of younger patients in our series.

CRVO in younger patients is probably a different disease from that seen in more elderly patients. Previous authors ${ }^{3-712}$ have noted the unilaterality of the retinopathy, its good visual prognosis, and, when patients have been followed for any length of time, its good systemic prognosis. These results are compatible with our own study. The typical fundus appearance is of unilateral optic disc swelling with a moderate degree of retinal haemorrhage, but retinal ischaemia of any severity is uncommon. Optic disc swelling in younger patients with CRVO appears to be more common and more marked than in the elderly. The reason for this in the absence of overt ischaemia is not clear but may reflect the greater number of viable axons in a younger eye, with more axoplasm therefore being passed along the optic nerve.

The most serious threat to vision in our series was concomitant occlusion of a cilioretinal artery at presentation, related to compression of that artery by increased tissue pressure within the optic disc. McLeod and Ring ${ }^{13}$ found a cilioretinal supply in 26 of 146 cases of CRVO, and in seven of these there were signs of an associated cilioretinal infarct. Poor acuity at presentation tended to correlate with more pronounced optic disc oedema.

Follow-up data on visual recovery were available for 11 of our 17 patients and showed a generally good prognosis (Fig 2, Table IV), as others have found. Macular oedema was responsible for the poor visual recovery in three patients; one of these was associated with acute anterior uveitis and another with cilioretinal artery occlusion. The remaining seven patients (64\%) improved to $6 / 9$ or better. No patient developed rubeosis. The good visual prognosis in these patients contrasts with that expected in the elderly. Rubenstein and Jones ${ }^{14}$ studied 143 patients aged 30 and over and found that $59 \%$ had a visual acuity of $6 / 18$ or worse in the affected eye and $36 \%$ less than $6 / 60$.

Only one patient in our series developed disease in the fellow eye during follow-up, and this patient $(Q)$ was in many ways atypical. At 14 years of age he was the youngest patient in the series. He presented with an overt non-specific immunological illness with arthralgia and a CRVO in the left eye, erythrocyte sedimentation rate, anaemia, raised serum globulins, and inflammatory changes seen on a liver biopsy. Five months later he developed a CRVO in the fellow eye. He was treated with systemic steriods, and the retinopathy resolved, eventually leaving him with a visual acuity of $6 / 6$ and $6 / 2418$ months later, the reduced acuity in the left eye being due to cilioretinal artery occlusion.

Patient $Q$ was the only patient to have evidence of an inflammatory or immunological underlying disease process which might account for the CRVO. Patient F had ankylosing spondylitis, but this is not typically associated with systemic vasculitis and was probably coincidental to the retinopathy. Although 10 patients had conditions that predispose to premature vascular disease, they must be considered in the context of the general incidence in the population, and it is difficult to draw any conclusions that these conditions were responsible for the retinopathy. Indeed the absence of involvement of the fellow eye or the lack of development of other systemic vascular disease on follow-up argues against a premature tendency to arterial disease. Caution must be taken though, as patient $\mathrm{A}$ did suffer a cerebrovascular accident eight years later (unfortunately we have no further details of this illness). No patient in our 
series had systemic hypertension. Dobson and Kritzinger ${ }^{\text {s }}$ examined 87 patients with CRVO or branch retinal vein occlusion (BRVO), of whom 40 were under 50 years of age. They found a decreased incidence of systemic hypertension in the younger patients $(27 \%$ of hypertension versus $62 \%$ in the over $50 \mathrm{~s}$ ), but $35 \%$ of their younger patients had hyperlipidaemia and four were on the contraceptive pill. From this paper it is impossible to differentiate those patients with BRVO where hypertension is a more likely cause from those with a CRVO.

Although eight of our 17 patients had a lipid screen, no abnormality was found in any of them. Other studies of CRVO in young patients have failed to show any carotid arterial disease on doppler ultrasonography ${ }^{16}$ or evidence of inflammatory aetiology. ${ }^{17}$. Fruch et al ${ }^{19}$ studied 11 patients with CRVO under the age of 45 . Seven had severe retinal ischaemia, and five of these had diabetes (2), hypertension (4), and systemic lupus erythematosus (1), whereas the four patients without retinal ischaemia had no systemic disease. Priluck et $a l^{12}$ reviewed 42 patients aged 40 years or younger when CRVO was diagnosed. They found no direct evidence that a vasculitis was a contributory factor. Eight (19\%) of their patients were found to have a systemic disease ( 3 with hpyertension, 2 with diabetes mellitus, 1 with valvular heart disease, 1 with polymyositis, and 1 with polycycstic kidneys). The follow-up period for their patients ranged from three to 26 years (average 14 years), and a further eight patients acquired a systemic disease during that time. Two had hypertension, two suffered 'cardiac death', and four had systemic diseases judged to be unrelated to CRVO. They found (as we did) that the visual prognosis tended to be good and that the incidence of involvement of the other eye was minimal (in only two cases).

As to pathology, it seems reasonable to adopt Virchow's approach ${ }^{19}$ regarding factors concerned in the causation of thrombosis. These are changes in the vessel wall, changes in the blood flow, and changes in the composition of the blood.

A vasculitis of the venous wall has been frequently cited s-7 $172122^{2}$ as a primary cause of CRVO in young adults. It does seem improbable, though, that an inflammatory process should be limited to a few millimetres of vein in one optic nerve head. One might expect to find signs of systemic vasculitis or, at the very least, a substantial incidence of bilateral CRVO. Clinical experience in this study and others shows this is not the case in the great majority of patients. Furthermore, there is no real histological evidence to support this concept. It is difficult to obtain material for histopathological study early in the course of the disease. Most eyes obtained have been removed because they were blind and painful owing to the onset of rubeotic glaucoma weeks or months after the CRVO. In these eyes round cell infiltrate of the perivenular area, intramural region, and within the lumen has been observed. ${ }^{52123}$ Green $e t a l^{23}$ did a histopathological study on two eyes with CRVO (patients aged 32 and 56 years) enucleated within 24 hours of onset. These showed that the acute inflam-
TABLE VII Suggested investigations for young patients with CRVO

Full blood count, ESR

Plasma viscosity and fibrinogen

Urea, electrolytes, plasma proteins (and electrophoresis)

Random serum glucose

Fasting lipid pro

Autoantibody screen

Electrocardiogram

Chest $x$-ray

^Venereal disease research laboratory test/Treponema pallidum haemagglutination test.

matory changes expected in any venous thrombosis (polymorphonuclear cell infiltrate) and vasculitis were not thought to be a contributary factor. They went on to study a further 24 cases (aged 44 to 91) enucleated from two weeks to five years after the CRVO, which generally showed a perivenous round cell infiltrate consistent with chronic inflammation. They convincingly argue that this chronic inflammatory infiltrate is the result of the CRVO and not the cause. Endothelial cell proliferation has been suggested as a cause of CRVO. ${ }^{20}$ Green et $a l^{23}$ again demonstrated this as a frequent finding in longstanding CRVO but not in the acute phase. They state that this endothelial proliferaton is the result of the repair process and not a causative factor.

Conditions such as hyperlipidaemia, paraproteinaemias, polycythaemia, increased platelet aggregation, and other hyperviscosity or hypercoagulability syndromes which result in changes in the composition of the blood (and its flow) have often been found in association with CRVO. These factors were not a prominent feature in our series but can undoubtedly be associated with CRVO, ${ }^{911} 15^{24-26}$ and it is important to exclude them in all young patients. It does, however, appear that most young patients with CRVO have a uniocular loss with a low risk of involvement of the fellow eye, an extremely low chance of any systemic inflammatory illness being found, and a low risk of any underlying vascular or atherogenic disease. Prolonged follow-up in our series and others ${ }^{312}$ indicates that most patients continue to have excellent general health.

A hypothesis which might explain these findings would be the presence of a congenital anomaly in the central retinal vein at the lamina cribrosa causing turbulent flow and predisposing to thrombus formation.

We consider that young adults with CRVO require comprehensive physical examination and investigation. Our suggestions for these investigations are set out in Table VII.

We are most grateful to Mr T J Ffytche, Mr M D Sanders, and $\mathrm{Mr}$ J S Shilling, who kindly allowed us to study patients under their care.

1 Kohner EM, Cappin JM. Do medical conditions have an influence on central retinal vein occlusions? Proc $R$ Soc Med 1974; 67: 1052-4.

2 Vannas S, Raitta C. Anticoagulant treatment of retinal venous occlusions. Am f Ophthalmol 1966; 62: 874-84.

3 Lyle TK, Wybar K. Retinal vasculitis. Br f Ophthalmol 1961; 45: 778-88.

4 Lonn CI, Hoyt WF. Papillophlebitis - a cause of protracted yet benign optic disc edema. Ear Nose Throat f 1966 ; 45: 62-8.

5 Cogan DG. Retinal and papillary vasculitis. In: Cant JS, Ed. William Mackenzie centenary symposium on ocular circulation in health and disease. London: Kimpton, 1968: 249-70. 6 Hart CS, Sanders MD, Miller SJH. Benign retinal vasculitis: 
clinical and fluorescein angiographic study. Brf Ophthalmol 1971; 55: 721-33.

7 Hayreh SS. Optic disc vaculitis. Br $\mathcal{F}$ Ophthalmol 1972; 56: 652-70.

8 Dobson PM, Galton DJ, Hamilton AM, Blach RK. Retinal vein occlusion and the prevalence of lipoprotein abnorvein occlusion and the prevalence of lipop

9 Brown GC, Shah HG, Magargal LE, Savino PJ. Central retinal vein obstruction and carotid artery disease. Ophthalmology 1984; 91: 1627-33.

10 Frucht J, Shapiro A, Merm S. Intraocular pressure in retinal vein occlusion. Brf Ophthalmol 1984; 68: 26-8.

11 Ring CP, Pearson TC, Sanders MD, Wetherley-Mein G. Viscosity and retinal vein thrombosis. BrF Ophthalmol 1976; 60: $397-409$.

12 Priluck IA, Robertson DM, Hollenhorst RW. Long-term follow-up of the central retinal vein in young adults. $A m \mathcal{F}$ Ophthalmol 1980; 90: 190-202.

13 McLeod D, Ring CP. Cilio-retinal infarction after retinal vein occlusion. Br f Ophthalmol 1976; 60: 419-30.

14 Rubenstein K, Jones EB. Retinal vein occlusion: long term prospects, 10 years follow-up of 143 patients. $\mathrm{Br} \mathcal{F} \mathrm{Oph}$ prospects, 10 years follow
thalmol $1976 ; 60: 148-50$

15 Dobson PM, Kritzinger EE. Underlying medical conditions in young patients and ethnic differences in retinal vein occluyoung patients and ethnic differences in retinal vein occlu-
sion. Trans Ophthalmol Soc UK 1985; 105: 114-9.

16 Bettleheim H, Fortis N. Doppler Ultrasonographie (DUSG) der orbitalen Gefasse bei Durchblutungsstorungen des Auges. Klin Monatsbl Augenheilkd 1985; 187: 187-90.

17 Lalive d'Epinay S. Vaskulitis der papille. Klin Monatsbl Augenheilkd 1982; 180: 486-8.

18 Frucht J, Yanko L, Merin S. Central retinal vein occlusion in young adults. Acta Ophthalmol (Kbh) 1984; 62: 780-6.

19 Walter JS, Israel MS. General pathology. 5th ed. Edinburgh: Churchill Livingstone, 1979: 489.

20 Klein BA. Occlusion of the central retinal vein. Clinical importance of certain histopathologic observations. $A m \mathcal{F}$ Ophthalmol 1953; 36: 316-24.

21 Appen RE, De Venecia G, Ferwerda J. Optic disc vasculitis. Am 7 Ophthalmol 1980; 90: 352-9.

22 Hunter CP, Thompson HS. Papillophlebitis. Curr Concepts Ophthalmol 1974; 4: 353-61.

23 Green RW, Hutchins GM, Terry JM. Central retinal vein occlusion: a prospective histopathologic study of 29 eyes in 28 cases. Trans Am Ophthalmol Soc 1981; 79: 371-421.

24 Dodson PM, Galton DJ, Winder AF. Retinal vascular abnormalities in the hyperlipidaemias. Trans Ophthalmol Soc UK 1981; 101: 17-21.

25 Dodson PM, Westwick J, Marks G, Kakkar BB, Galton DJ. B-thromboglobulin and platelet factor: 4 levels in retinal vein occlusion. Br f Ophthalmol 1983; 67: 143-6.

26 Foulds WS. 'Blood is thicker than water', some haemorrheological aspects of ocular disease. Eye 1987; 1: 34363. 